\title{
The Effect of Time, Temperature and Solid to Solvent Ratio on Pumpkin Carotenoids Extracted Using Food Grade Solvents
}

(Kesan Masa, Suhu dan Nisbah Pepejal kepada Pelarut ke atas Karotenoid Labu yang Diekstrak Menggunakan Pelarut Gred Makanan)

\section{NORSHAZILA S.,* KoY C.N., RASHidi O., Ho L.H., AZRINA I, NuRUl ZaizUlianA R.A. \& ZARINAH Z}

\begin{abstract}
This study aimed to extract carotenoids from pumpkin (Cucurbita moschata) by using food grade solvents (ethanol, ethyl acetate, acetic acid and virgin coconut oil). The influence of different extraction conditions; temperature of extraction $\left(15,30\right.$ and $\left.45^{\circ} \mathrm{C}\right)$, duration of extraction $(12,18$ and $24 \mathrm{~h})$ and solid to solvent ratio $(1: 50,1: 100$ and 1:150) on yield of carotenoids were also evaluated for optimization purposes. The compounds of the extracted carotenoids were identified by using high performance liquid chromatography (HPLC). The detected carotenoids from pumpkin had been $\alpha$-carotene, $\beta$-carotene and lutein. Lutein was found to have the highest concentration in pumpkin. Furthermore, the results obtained from the yield of carotenoids showed that sample extracted with ethyl acetate was insignificant and this differed from that with virgin coconut oil extract (77.30 and $76.64 \beta$-carotene $\mu \mathrm{g} / \mathrm{g}$ dry matter, respectively). Meanwhile, the samples extracted by using either acetic acid or ethanol had presented low yields (68.10 and $54.98 \beta$-carotene $\mu \mathrm{g} / \mathrm{g}$ dry matter, respectively). Nevertheless, the extract of carotenoids was found to be optimized at the following extraction conditions; 1:150 solid to solvent ratio and extracted by using virgin coconut oil for $12 \mathrm{~h}$ at $30^{\circ} \mathrm{C}$.
\end{abstract}

Keywords: Carotenoids; extraction; food grade solvent; high-performance liquid chromatography; pumpkin

ABSTRAK

Kajian ini bertujuan untuk mengekstrak karotenoid daripada Labu (Cucurbita moschata) dengan menggunakan pelarut gred makanan (etanol, etil asetat, asid asetik dan minyak kelapa dara). Pengaruh keadaan pengekstrakan berbeza; suhu ekstrakan $\left(15,30\right.$ dan $\left.45^{\circ} \mathrm{C}\right)$, masa ekstrakan $(12,18$ dan 24 h) dan nisbah pepejal kepada pelarut (1:50, 1: 100 dan 1:150) pada hasil karotenoid juga telah dinilai untuk tujuan pengoptimuman. Sebatian karotenoid yang diekstrak telah dikenal pasti dengan menggunakan kromatografi cecair prestasi tinggi (HPLC). Karotenoid yang dikesan daripada labu ialah $\alpha$-karotena, $\beta$-karotena dan lutein. Lutein didapati mempunyai kepekatan tertinggi dalam labu. Selain itu, keputusan yang diperoleh daripada hasil karotenoid menunjukkan sampel yang diekstrak menggunakan etil asetat tidak menunjukkan perbezaan bererti dan ini berbeza daripada ekstrak minyak kelapa dara (77.30 dan $76.64 \beta$-karotena $\mu \mathrm{g} / \mathrm{g}$ jirim kering). Sementara itu, sampel yang diambil sama ada menggunakan asid asetik atau etanol telah menghasilkan tuaian yang rendah (68.10 dan 54.98 -karotena $\mu \mathrm{g} / \mathrm{g}$ jirim kering). Walau bagaimanapun, ekstrak karotenoid didapati dioptimumkan pada keadaan ekstrakan berikut; 1:150 nisbah pepejal kepada pelarut dan diekstrak dengan menggunakan minyak kelapa dara selama $12 \mathrm{~h}$ pada $30^{\circ} \mathrm{C}$.

Kata kunci: Karotenoid; kromatografi cecair berprestasi tinggi; labu; pelarut gred makanan; pengekstrakan

\section{INTRODUCTION}

Carotenoids are plant pigments that are composed of more than 700 natural compounds and their structures are similar to vitamin A. However, only 50 natural compounds of carotenoids exhibit provitamin A activity. Carotenoids can be classed into two groups, which consist of hydrocarbons (carotenes) and their oxygenated derivatives, which are known as xanthophylls (Man \& Tan 2012).

Pumpkins belong to the family of Cucurbitaceae (Xanthopoulou et al. 2009), similar to melons, cucumbers, gourds, and different varieties of squash (Bratsch 2009). The annual crop statistics recorded that the production of pumpkin in Malaysia ranged from 11185 tonnes of metric to 21413 tonnes of metric from year 2009 to 2013 (MOA 2013).
Pumpkin is planted throughout the year and it is one of the abundant crops planted in Malaysia. Even though this crop has been widely used in the Malay cuisine, unfortunately, not many researches have focused on its carotenoids compound for food and health industries. Nevertheless, Norshazila et al. (2014) reported that carotenoids, such as $\alpha$-carotene, $\beta$-carotene and lutein, are present in pumpkin pulp. Pumpkin is an excellent source of carotenoids for food and pharmaceutical industries. Therefore, the present study investigated the optimum conditions for carotenoids extraction. Besides, the solvents chosen for carotenoids extraction were of food grade solvents to minimize toxicity level and for safe consumption. Hence, pumpkin can be well-utilized from its benefits. 
Carotenoids are a group of hydrophobic molecules with very low aqueous solubility and they function in hydrophobic areas of the cell (Jomova \& Valko 2013). Thus, oil- and petroleum-based solvents are very suitable for extraction of carotenoids compound. Organic solvents are the popular solvents for carotenoids extraction. However, the concern in using organic solvents for extraction is the toxic effects and the high cost of the extraction process (Fikselova et al. 2008). Nonetheless, a few environmentally friendly solvents can be used to extract carotenoids for foods fortification or supplement purposes. According to Ishida and Chapman (2009), the most effective known solvents are of products from the petroleum industry. However, they are unsafe for human consumption. Traditionally, organic solvent extraction (CSE) is a popular method applied to extract carotenoids. The common solvents used in CSE for extraction of carotenoids are n-hexane, propanol, methanol or tetrahydrofuran. However, CSE method requires long extraction time, large volume of organic solvent and high temperature that result in extensive degradation of carotenoids, as well as leave trace amounts of potentially toxic residues in the extract (Durante et al. 2014). On the other hand, Supercritical Fluid Extraction (SFE) that uses carbon dioxide as a supercritical fluid is a non-hazardous and non-flammable extraction method. However, it requires high operating pressures and high capital investment for equipment (Othman et al. 2010). In addition, carotenoids can be produced through fermentation process, however, the disadvantage of the fermentation process is the mechanical milling applied to disrupt the cell membrane that might lead to the loss of carotenoids (Joseph \& Anandane 2011).

The yield of the total carotenoids extraction is determined by the characteristics of solvent, solid to solvent ratio, repeated extraction cycles and conditions of extraction; time and temperature of extraction (Wang \& Liu 2009). In the present study, different organic solvents such as ethanol, ethyl acetate, acetic acid and virgin coconut oil, were used to optimize the extracts yield obtained. Carotenoid was extracted from pumpkin flesh by using a conventional method. This was attributed to virgin coconut oil, which is unable to evaporate, by using nitrogen gas due to its low melting point as it contains high amount of medium chain saturated fatty acids. The optimization parameters were time of extraction, temperature of extraction and solid to solvent ratio of extraction. The carotenoids extract was identified using high-performance liquid chromatography (HPLC) analysis. Thus, the results obtained from the present study are expected to provide a new set of data on the optimum conditions for carotenoid extraction.

\section{MATERIALS AND METHODS}

\section{MATERIALS}

Pumpkins (Cucurbita moschata) and virgin coconut oil were purchased from a local market in Terengganu,
Malaysia. The solvents (ethanol, ethyl acetate, acetic acid and virgin coconut oil) used in carotenoids extraction were of food grade. All the chemicals used in the samples analyses were of analytical grade.

\section{METHODS}

\section{PREPARATION OF PUMPKIN POWDER}

Pumpkin was rinsed under running tap water and the skin was peeled with a sterile knife. The pulp was sliced, dried overnight at $30^{\circ} \mathrm{C}$ in a cabinet dryer and was ground prior to analysis.

\section{CAROTENOIDS EXTRACTION}

The extraction of carotenoids from the pumpkin was performed as described by Shahidan (2014) with minor modifications. Approximately $100 \mathrm{mg}$ of pumpkin powder was suspended in $5 \mathrm{~mL}$ of solvent extract and it was allowed to stand overnight in darkness at room temperature. The mixture was then vortexed and centrifuged at $9383 \times \mathrm{g}$ for $15 \mathrm{~min}$ prior to being filtered. The supernatant was transferred into a $50 \mathrm{~mL}$ centrifuge tube and this process was repeated until colorless filtrate was observed. The combined supernatant was partitioned by adding equal volume of solvents to distilled water and then centrifuged at $9383 \times \mathrm{g}$ for $15 \mathrm{~min}$ to allow better separation. The carotenoid extracts were collected and stored at $-20^{\circ} \mathrm{C}$ for further analysis. The highest extract yield of carotenoids obtained was selected for optimization. In the present study, virgin coconut oil was selected due to its natural properties; healthy and safe for human consumption. In addition, one-factor-at-a-time (OFAT) principle was used to determine the optimum condition for carotenoid extraction. The optimization parameters were at temperature of extraction: 15, 30 and $45^{\circ} \mathrm{C}$; duration of extraction: 8,12 and $16 \mathrm{~h}$; and solid to solvent ratio: 1:50, 1:100 and 1:150.

\section{QUANTIFICATION OF TOTAL CAROTENOIDS BY USING SPECTROPHOTOMETER}

The total carotenoids extracted from different solvents, extraction temperatures, extraction time and solid to solvent ratio were measured by using Ultraviolet-Visible (UV-vis) spectrophotometer; based on the method proposed by Dauqan (2011), with some modifications. The total concentration of carotenoids was calculated according to the equation described by Rodriguez-Amaya and Kimura (2004):

$$
\begin{aligned}
& \text { Total carotenoid } \\
& \text { content }(\mu \mathrm{g} / \mathrm{g})
\end{aligned}=\frac{\mathrm{A}(\text { total }) \times \text { volume }(\mathrm{mL}) \times 10^{4}}{\mathrm{~A} \times \text { sample weight }(\mathrm{g})},
$$

where $\mathrm{A}$ is the absorbance value of extract at $450 \mathrm{~nm}$; and $\mathrm{A}$ is the extinction coefficient of carotenoids. 
IDENTIFICATION OF CAROTENOIDS BY USING HIGHPERFORMANCE LIQUID CHROMATOGRAPHY (HPLC)

The carotenoids composition of the pumpkin was analyzed by using HPLC (Agilent model 2100 series, United States) that comprised of ZORBAX Eclipse XDB-C18 column, a binary pump with auto sample injector (injection volume was $10 \mu \mathrm{L}$ ), micro vacuum degassers, thermostat column compartment and a diode array detector. The mobile phase was (A) acetonitrile: water (9:1 v/v) and (B) ethyl acetate. The solvent gradient used was developed; $0-40 \%$ solvent B (0-20 min), 40-60\% solvent B (20-25 min), 60-100\% solvent B (25-25.1 min), 100\% solvent B (25.1-35 min) and $100-0 \%$ solvent $B(35-35.1 \mathrm{~min})$ at a flow rate of $1.0 \mathrm{~mL}$ $\mathrm{min}^{-1}$ and the column temperature was controlled at $20^{\circ} \mathrm{C}$.

Standard carotenoid solutions of $\beta$-carotene, $\alpha$-carotene and lutein were prepared at the concentrations of $0.2,0.4,0.6,0.8$ and $1.0 \mathrm{mg} / \mathrm{mL}$. Besides, standard curves were plotted for all carotenoid solutions based on the area against concentration $(\mathrm{mg} / \mathrm{mL})$. The retention time (RT) of lutein, $\alpha$-carotene and $\beta$-carotene were at 16.9,29.7 and $29.9 \mathrm{~min}$. Individual carotenoid concentrations were also calculated by comparing their relative proportions, as reflected in the integrated HPLC peak areas (Shahidan 2014).

\section{STATISTICAL ANALYSIS}

The results obtained in the present study are represented as mean values of three individual replicates \pm standard deviation (s.d.). One-way analysis of variance was performed with statistics software program by using the IBM SPSS Statistic version 20.0. The significant differences between the mean values were determined by using the Duncan's multiple range test at a significance level of $p<0.05$.

\section{RESULTS AND DISCUSSION}

\section{EFFECTS OF TYPES OF SOLVENTS ON TOTAL CAROTENOIDS YIELD}

The results of the total carotenoid yield extracted by using four different food grade solvents are presented in Table 1. The total amount of carotenoid obtained from ethanol and acetic acid extractions displayed significantly $(p<0.05)$ lower content of yield (54.98 and $68.10 \beta$-carotene $\mu \mathrm{g} / \mathrm{g}$ dry matter, respectively) than the carotenoid extracted by using ethyl acetate and virgin coconut oil (77.30 and $76.64 \beta$-carotene $\mu \mathrm{g} / \mathrm{g}$ dry matter, respectively). This was attributed to the difference in polarity of the extraction solvents. According to Reichardt (2003), the relative polarity of ethyl acetate, acetic acid and ethanol are 0.228 , 0.648 and 0.654 , respectively. Therefore, ethyl acetate has less polarity as compared to the other two solvents (acetic acid and ethanol). Furthermore, Iwata and Shimada (2012) reported that hydrocarbons have the lowest polarity and followed by waxes, vegetable oils and fats, esters, higher alcohols and fatty acids. Thus, virgin coconut oil has been the most non-polar among the four types of solvents used in this study. However, there was no significant difference between carotenoid content in ethyl acetate and virgin coconut oil. The higher total carotenoids content obtained from ethyl acetate and virgin coconut oil extraction might be attributed to the non-polar property of the solvents, due to the fact that the carotenoids content is calculated based on the total $\beta$-carotene (a non-polar carotenoid) released.

In addition, the effectiveness of extraction is largely determined by the natural properties of the solute with solvents that can dissolve them based on the polarity (Warkoyo \& Saati 2011). Besides, carotenoids exhibit different co-solubilization properties, which depend to the polarity of the solvents. Non-polar carotenoids, such as lycopene and $\beta$-carotene are solubilized in non-polar solvent, while a polar carotenoid, such as lutein or epoxy carotenoids, shows greater solubility in polar solvents (Rivera \& Canela 2012). Moreover, the results obtained from the present study are in accordance with the results recorded by Strati and Oreopoulou (2011). The authors reported that the total carotenoids yield extracted with ethyl acetate was higher than the total carotenoids yield extracted by using ethanol.

On top of that, according to Rodriguez-Amaya and Kimura (2004), water-miscible polar organic solvents, such as ethanol, is recommended for the extraction of carotenoids from tissues containing water and it can be considered as a good extraction solvent for xanthophylls, but not for carotenes. Hence, ethanol extraction presented the lowest carotenoid yield as compared to the other solvents. However, the most suitable solvents used to extract carotenoids from pumpkin were ethyl acetate and virgin coconut oil as they demonstrated high yield of carotenoids. Hence, virgin coconut oil was chosen as the solvent for further optimization study for it is natural and safe for consumption.

\section{EFFECTS OF EXTRACTION TEMPERATURE ON TOTAL CAROTENOIDS YIELD}

The results obtained from total carotenoids yield extracted at different temperatures $\left(15,30\right.$ and $\left.45^{\circ} \mathrm{C}\right)$ are tabulated in Table 2. The total carotenoids extracted from virgin coconut oil at $30^{\circ} \mathrm{C}$ showed the significantly $(p<0.05)$ highest yield ( $81.47 \beta$-carotene $\mu \mathrm{g} / \mathrm{g}$ dry matter) than the

TABLE 1. Effect of different types of solvent on the carotenoid yield of pumpkin

\begin{tabular}{lc}
\hline Types of solvent & $\begin{array}{c}\text { Total carotenoid content } \\
(\beta \text {-carotene } \mu \mathrm{g} / \mathrm{g})\end{array}$ \\
\hline Ethanol & $54.98^{\mathrm{a}} \pm 1.59$ \\
Ethyl acetate & $77.30^{\mathrm{c}} \pm 4.43$ \\
Acetic acid & $68.10^{\mathrm{b}} \pm 5.23$ \\
Virgin coconut oil & $76.64^{\mathrm{c}} \pm 4.63$ \\
\hline
\end{tabular}

Presented data are mean value of three replications \pm standard deviation $(n=3 \pm$ s.d.) Mean values in the same column with different superscript letters are differ significantly from each other $(p<0.05)$ 
total carotenoids obtained from extraction temperature at 15 and $45^{\circ} \mathrm{C}(74.45$ and $76.30 \beta$-carotene $\mu \mathrm{g} / \mathrm{g}$ dry matter, respectively). Increase in yield of carotenoids extracted at temperature from 15 to 30 was attributed to the heat that could promote the extraction of solutes. According to Aflaki (2012), the carotenoids in plants are enclosed within cells and the cell membrane is composed of a complex composition. When the temperature is increased, it facilitates the breakdown of cell wall and improves their extraction with solvent. In addition, heat below the degradation temperature of carotenoids could facilitate the extraction of solute by increasing the permeability of cell walls to the solvent and this leads to an increase in the solubility of carotenoids; increasing the diffusion coefficients and decreasing the viscosity of the solvent during extraction.

Other than that, Oliveira et al. (2010) reported that carotenoid degradation occurs in temperature close to $40^{\circ} \mathrm{C}$. Therefore, temperature up to $45^{\circ} \mathrm{C}$ resulted in a decrease in the yield of carotenoids content (Table 2). Moreover, a previous study carried out by Das and Bera (2013) showed that the extraction yield of $\beta$-carotene was maximum at $40^{\circ} \mathrm{C}$ and decreased at further increase of temperature. In fact, the present findings are similar to the results reported by Das and Bera (2013), where carotenoid yield decreased at 45 . Furthermore, $\beta$-carotene exists in the natural all-trans form, as high temperature causes extensive isomerization and some parts of alltrans form are converted into various cis-isomers. Thus, isomerization could be considered as a negative effect of processing since cis-isomers have less provitamin A activity than trans-isomers. Isomerization can occur in provitamin A carotenoids at temperatures above $35^{\circ} \mathrm{C}$. The conjugated double bonds and the electron rich system of carotenoids are unstable towards oxidation due to attraction for electrophilic molecules (Bechoff 2010).

TABLE 2. Effect of different extraction temperatures on the carotenoid yield of pumpkin

\begin{tabular}{cc}
\hline $\begin{array}{c}\text { Temperature } \\
\left({ }^{\circ} \mathrm{C}\right)\end{array}$ & $\begin{array}{c}\text { Total carotenoid content }(\beta \text {-carotene } \\
\mu \mathrm{g} / \mathrm{g})\end{array}$ \\
\hline 15 & $74.45^{\mathrm{a}} \pm 1.36$ \\
30 & $81.47^{\mathrm{b}} \pm 2.32$ \\
45 & $76.30^{\mathrm{ab}} \pm 3.80$ \\
\hline
\end{tabular}

Presented data are mean value of three replications \pm standard deviation $(n=3 \pm$ s.d. $)$ Mean values in the same column with different superscript letters are differ significantly from each other $(p<0.05)$

\section{EFFECTS OF EXTRACTION DURATION ON TOTAL CAROTENOIDS YIELD}

The results of extraction time (h) on total carotenoid yield are shown in Table 3. The duration (time) of extraction did not significantly $(p>0.05)$ influence the total carotenoids yield $(72.98,76.11$ and $76.64 \beta$-carotene $\mu \mathrm{g} / \mathrm{g}$ dry matter for 12,18 and $24 \mathrm{~h}$ of extraction, respectively). The total carotenoids content decreased insignificantly from 12 to
$24 \mathrm{~h}$ of extraction time. Besides, Roohinejad et al. (2014) reported that by increasing the extraction time, $\beta$-carotene could be solubilized in the oil matrix and released to the solvent. The results obtained from the present study showed that the extraction of carotenoids for $12 \mathrm{~h}$ may be sufficient for the optimum amount of carotenoids to be dissolved in the solvent. Furthermore, according to Strati and Oreopoulou (2011), in a solid-liquid extraction process, penetration or diffusion of solute of solvent to the surface of solid or particles and dissolution of the solute into the solvent may occur. Hence, the rate of extraction is controlled by diffusion phenomena. Strati and Oreopoulou (2011) also reported that the extraction yield increased with time, then decreased with time until an equilibrium condition was achieved in the solvent from 5 to $40 \mathrm{~min}$ of extraction time. However, the results obtained from the present study differed from the previous findings reported by Strati and Oreopoulou (2011). The extension of extraction duration above $18 \mathrm{~h}$, which was expected to increase the total carotenoids content due to equilibrium state, did not achieve.

TABLE 3. Effect of extraction duration (hours) on the carotenoid yield of pumpkin

\begin{tabular}{cc}
\hline Duration $(\mathrm{h})$ & Total carotenoid content $(\beta$-carotene $\mu \mathrm{g} / \mathrm{g})$ \\
\hline 8 & $72.98^{\mathrm{a}} \pm 6.98$ \\
12 & $76.11^{\mathrm{a}} \pm 5.96$ \\
16 & $76.64^{\mathrm{a}} \pm 4.63$ \\
\hline
\end{tabular}

Presented data are mean value of three replications \pm standard deviation $(n=3 \pm$ s.d.) Mean values in the same column with different superscript letters are differ significantly from each other $(p<0.05)$

Therefore, since no significant difference was detected in the total carotenoids yield among the three extraction durations, $12 \mathrm{~h}$ has been chosen as the optimum duration for carotenoid extraction due to the highest yield retrieved among those three treatments. The shortest extraction time was chosen in order to save the processing time, as well as to minimize the cost of production.

\section{EFFECTS OF SOLID TO SOLVENT RATIO ON TOTAL CAROTENOIDS YIELD}

Table 4 provides the results obtained for carotenoid yield calculated from different solid to solvent ratios. Extraction yield was significantly $(p<0.05)$ affected by solid to solvent ratio. In general, the total carotenoids yield increased as the solid to solvent ratio was increased (1:50 to $1: 150)$. The sample extracted in 1:150 (solid to solvent ratio) exhibited the highest yield of carotenoids (171.96 $\beta$-carotene $\mu \mathrm{g} / \mathrm{g}$ dry matter). According to Das and Bera (2013), the rate of extraction depends on the concentration gradient between pumpkin particles and virgin coconut oil; with an increase in the solid to solvent ratio, the concentration gradients of carotenoids increased as well. Tan et al. (2011) stated that a high solid to solvent ratio increases concentration 
gradient, and hence, increases rate of diffusion. This allows greater extraction of solids by solvent. These results are, in fact, consistent with the mass transfer principles; the concentration gradient between solid and solvent becomes the driving force for mass transfer.

In addition, according to Lebovka et al. (2011), the concentration of solute changes continuously (nonstationary mass transfer) during extraction. Diffusion transfer is caused by the random movement of molecules with the concentration gradient as the driving force. Shi et al. (2002) reported that a higher solid to solvent ratio dilutes the concentration of dissolved carotenoids at the surface of the particles and provides a higher concentration gradient between the internal and the external surfaces of the particles. This phenomenon accelerates the rate of extraction. Furthermore, Tan et al. (2011) stated that increasing solid to solvent ratio increases the chance of carotenoid components coming into contact with extracting solvent. This produces a higher leaching-out rate of carotenoids to the solvent. However, the yield of active components will not continue to increase once equilibrium is reached.

On top of that, the previous findings from Das and Bera (2013) showed that the amount of carotenoids increased as the solid to solvent ratio was increased up to 1:40 as the equilibrium reached at 1:40 (solid to solvent ration). However, the results obtained from the present study showed that further increase in solid to solvent ratio significantly increased the carotenoid content. This was attributed to the equilibrium state that was not achieved. Hence, further extension of solid to solvent ratio was needed to performed in order to determine the equilibrium state between solid and solvent.

TABLE 4. Effect of solid to solvent ratio on the carotenoid yield of pumpkin

\begin{tabular}{cc}
\hline Solid to solvent ratio & $\begin{array}{c}\text { Total carotenoid content } \\
(\beta \text {-carotene } \mu \mathrm{g} / \mathrm{g})\end{array}$ \\
\hline $1: 50$ & $76.64^{\mathrm{a}} \pm 4.63$ \\
$1: 100$ & $113.55^{\mathrm{b}} \pm 5.46$ \\
$1: 150$ & $171.96^{\mathrm{c}} \pm 4.88$ \\
\hline
\end{tabular}

Presented data are mean value of three replications \pm standard deviation $(n=3 \pm$ s.d. $)$ Mean values in the same column with different superscript letters are differ significantly from each other $(p<0.05)$

\section{IDENTIFICATION OF CAROTENOID COMPOUNDS}

The concentrations of carotenoid compounds identified by using HPLC are presented in Table 5. The three types of carotenoids extracted from pumpkin were identified at retention time of 16.9, 29.7 and 29.9 min for lutein, $\beta$-carotene and $\alpha$-carotene, respectively (Figure 1 ). Lutein exhibited significantly $(p<0.05)$ higher concentration of carotenoid $(94.70 \mu \mathrm{g} / \mathrm{g}$ dry matter) than $\beta$-carotene (24.79 $\mu \mathrm{g} / \mathrm{g}$ dry matter $)$ and $\alpha$-carotene $(0.59 \mu \mathrm{g} / \mathrm{g}$ dry matter $)$. The results obtained from the present study are in accordance with the findings obtained by Murkovic et al. (2002). The authors reported that $\alpha$-carotene, $\beta$-carotene and lutein were detected from different varieties of pumpkins, such as Cucurbita pepo, Cucurbita maxima and Cucurbita moschata.

Another study performed by Norshazila et al. (2014) showed that the types of carotenoids detected in pumpkin grown in Besut, Terengganu were $\alpha$-carotene, $\beta$-carotene and lutein. Furthermore, the authors reported that the $\beta$-carotene presented the highest concentration and vice versa for lutein (the lowest concentration). However, the results obtained from the present study differed from the results reported by Norshazila et al. (2014), where lutein exhibited the highest concentration and $\alpha$-carotene presented the lowest concentration. This might be attributed to the several factors that affected the amount of carotenoids compositions, such as nature of the plant; fruits and vegetables; maturity stage; geographical factors; climate, soil condition and nutrient availability during agricultural production; as well as post-harvest handling, processing and storage condition of plants (Rodriguez-Amaya \& Mieko 2004). All these factors could significantly affect the biosynthesis and the metabolism of carotenoids in plants (Provesi et al. 2011).

TABLE 5. Carotenoids compound of pumpkin

\begin{tabular}{lc}
\hline Carotenoid & Concentration $(\mu \mathrm{g} / \mathrm{g})$ \\
\hline Lutein & $94.70^{\mathrm{a}} \pm 3.66$ \\
$\beta$-carotene & $24.79^{\mathrm{b}} \pm 3.20$ \\
$\alpha$-carotene & $0.59^{\mathrm{c}} \pm 0.08$ \\
\hline
\end{tabular}

Presented data are mean value of three replications \pm standard deviation $(n=3 \pm$ s.d. Mean values in the same column with different superscript letters are differ significantly from each other $(p<0.05)$

\section{CONCLUSION}

Optimization on the solid to solvent ratio, extraction time and temperature by using food grade solvent is indeed an important study for reproducible and optimum yield of pumpkin carotenoids extract. The results obtained in the current study suggested that the virgin coconut oil was the best food grade solvent than ethyl acetate due to its natural and safe properties for human consumption. Hence, this study established that virgin coconut oil can be a reliable source of food grade solvent for carotenoids extraction with the optimum conditions; 1:150 (solid to solvent ratio) and extracted for $12 \mathrm{~h}$ at $30^{\circ} \mathrm{C}$.

\section{ACKNOWLEDGMENTS}

We would like to thank UniszA Food Analysis lab and IIUM herbarium lab for the facilities provided and RAGS (RR 088) grant for the financial support. 


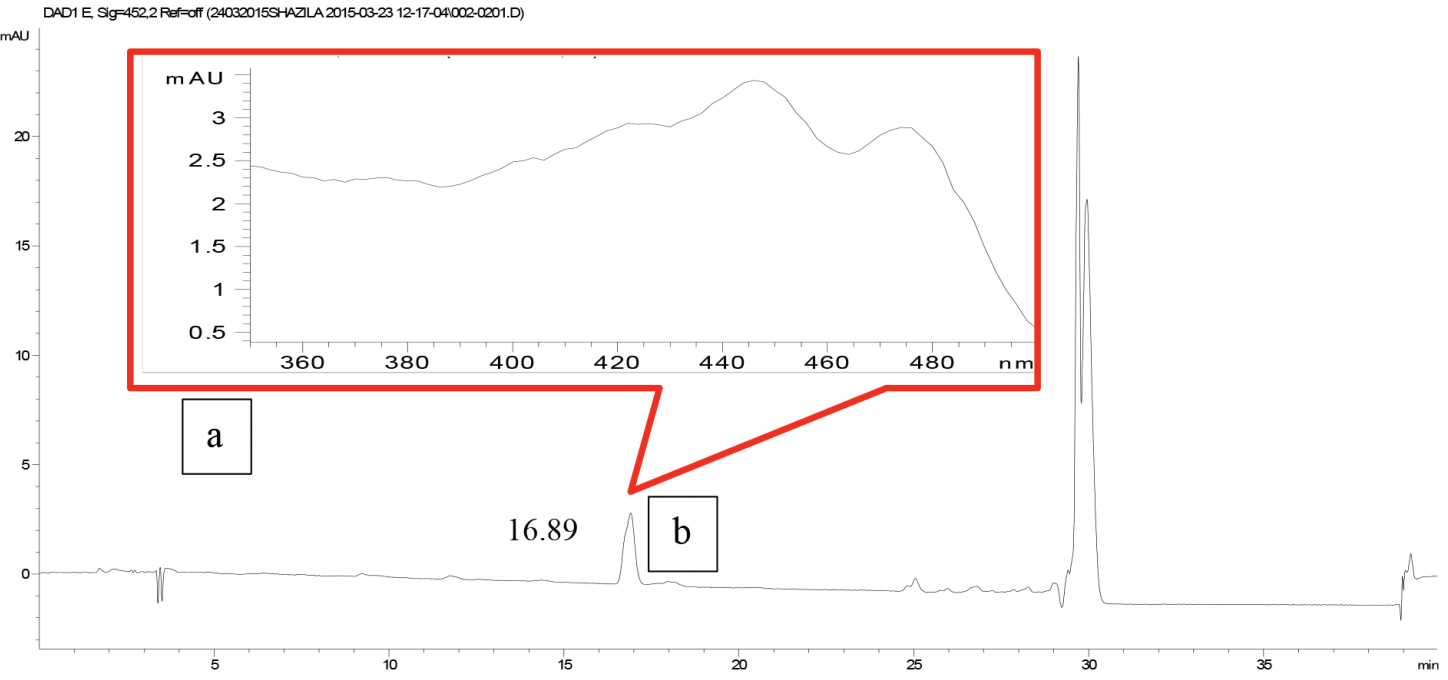

a. Spectral characteristic of lutein and (b) retention time of lutein: $16.9 \mathrm{~min}$

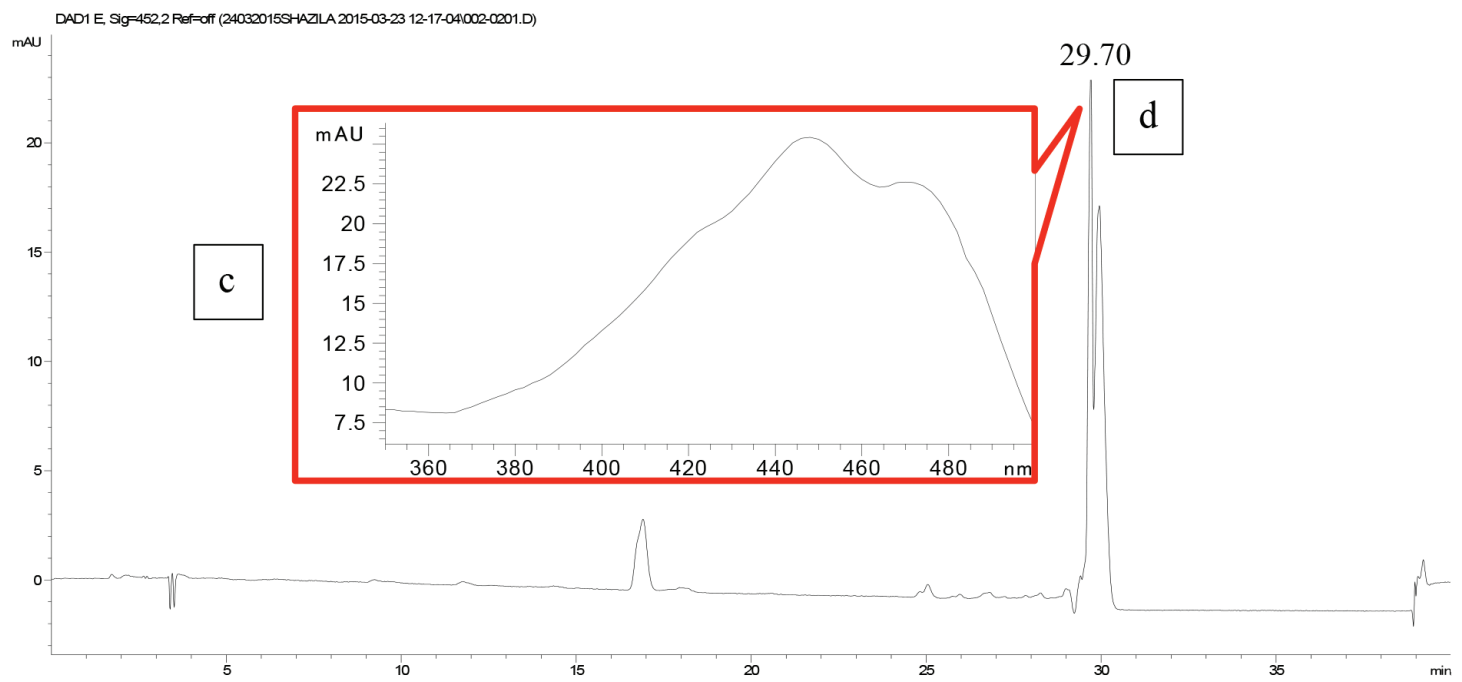

(c) spectral characteristic of $\alpha$-carotene and (d) retention time of $\alpha$-carotene: $29.7 \mathrm{~min}$

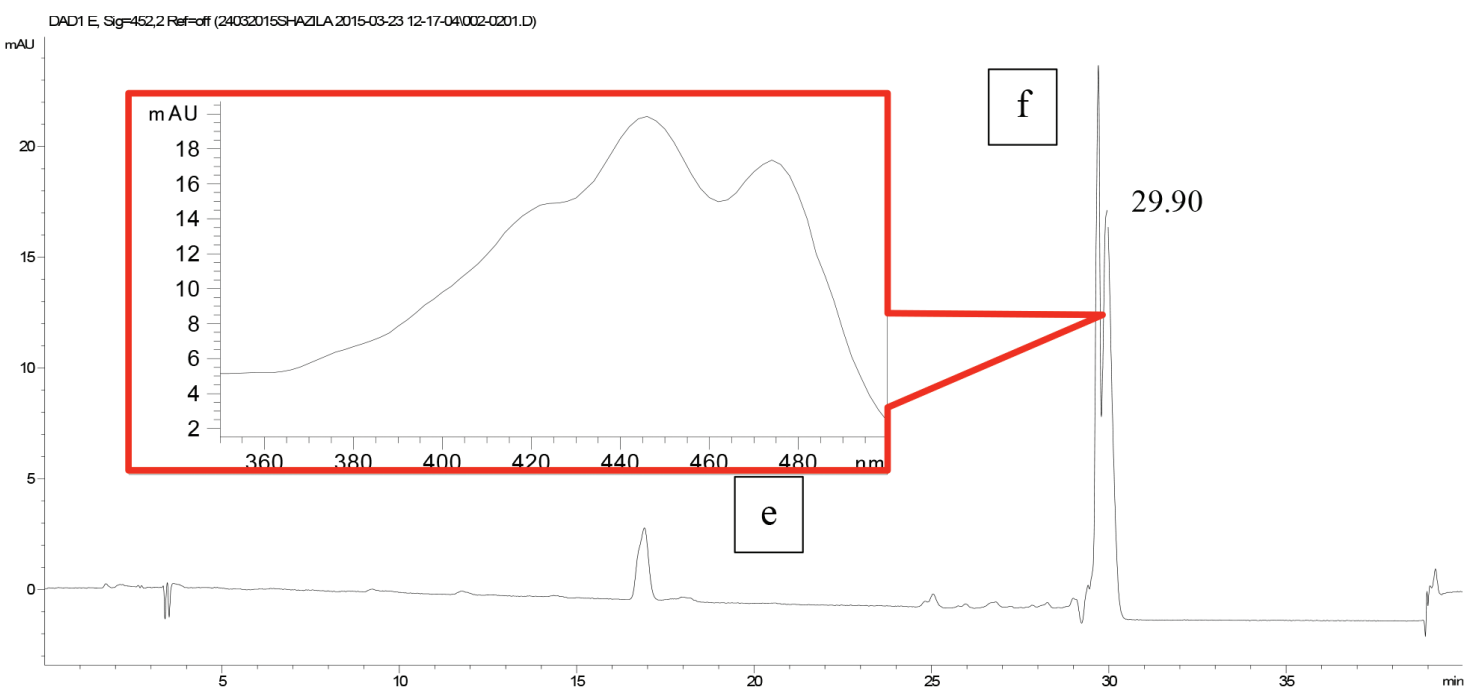

(e) spectral characteristic of $\beta$-arotene and (f) retention time of $\beta$-arotene: 29.9 min

FIGURE 1. High-performance liquid chromatography chromatograms of carotenoids in pumpkins 


\section{REFERENCES}

Aflaki, N. 2012. Optimization of carotenoid extraction in peel and flesh of cantaloupe (Cucumis melo L.), with ethanol solvent. MSc. thesis. Laval University, Canada.

Bechoff, A. 2010. Investigating carotenoid loss after drying and storage of orange-fleshed sweet potato. $\mathrm{PhD}$ thesis. University of Greenwich, United Kingdom.

Bratsch, A. 2009. Specialty crop profile: Pumpkins. Virginia Cooperative Extension 100: 1-8.

Das, S. \& Bera, D. 2013. Mathematical model study on solvent extraction of carotene from carrot. International Journal of Research in Engineering and Technology 2: 343-349.

Dauqan, E., Sani, H.A., Abdullah, A., Muhamad, H. \& Top, A.G. 2011. Vitamin E and beta carotene composition in four different vegetable oils. American Journal of Applied Sciences 8: 407-412.

Durante, M., Lenucci, M.S. \& Mita, G. 2014. Supercritical carbon dioxide extraction of carotenoids from pumpkin (Cucurbita spp.): A review. International Journal of Molecular Sciences 15: 6725-6740.

Fikselova, M., Silhar, S., Marecek, J. \& Francakova, H. 2008. Extraction of carrot (Daucus carota L.) carotenes under different conditions. Czech Journal of Food Sciences 26: 268-274.

Ishida, B.K. \& Chapman, M.H. 2009. Carotenoid extraction from plants using a novel, environmentally friendly solvent. Journal of Agricultural and Food Chemistry 57: 1051-1059.

Iwata, H. \& Shimada, K. 2012. Formulas, Ingredients and Production of Cosmetics: Technology of Skin- and HairCare Products in Japan. Japan: Springer Science \& Business Media.

Jomova, K. \& Valko, M. 2013. Health protective effects of carotenoids and their interactions with other biological antioxidants. European Journal of Medicinal Chemistry 70: $102-110$

Joseph, S. \& Anandane, A. 2011. Process for production of high purity beta-carotene and lycopene crystals from fungal biomass. United States Patent Application. WO2011145113 A2.

Lebovka, N., Vorobiev, E. \& Chemat, F. 2011. Enhancing Extraction Processes in the Food Industry. New York: CRC Press.

Man, Y.C. \& Tan, C.P. 2012. Carotenoids. In Lipids for Functional Foods and Nutraceutical, edited by Gunstone, F.D. Dundee, Scotland: Oily Press.

Murkovic, M., Mulleder, U. \& Neunteufl, H. 2002. Carotenoid content in different varieties of pumpkins. Journal of Food Composition and Analysis 15: 633-638.

Norshazila, S., Irwandi, J., Othman, R. \& Yumi Zuhanis, H.H. 2014. Carotenoid content in different locality of pumpkin (Cucurbita moschata) in Malaysia. International Journal of Pharmacy and Pharmaceutical Sciences 6: 29-32.

Oliveira, R.G.A., Carvalho, M.J.L., Nutti, R.M., Carvalho, L.V.J. \& Fukuda, W.G. 2010. Assessment and degradation study of total carotenoid and B-carotene in bitter yellow cassava (Manihot esculenta crantz) varieties. African Journal of Food Science 4: 148-155.

Othman, N., Manan, Z.A., Alwi, S.R.W.\& Sarmidi, M.R. 2010. A review of extraction technology for carotenoids and vitamin E recovery from palm oil. Journal of Applied Sciences 10: 1187-1191.
Provesi, J.G., Dias, C.O. \& Amante, E.R. 2011. Changes in carotenoids during processing and storage of pumpkin puree. Food Chemistry 128: 195-202.

Reichardt, C. 2003. Solvents and Solvent Effects in Organic Chemistry. Germany: Wiley-VCH Publishers.

Rivera, S. \& Canela, R. 2012. Influence of sample processing on the analysis of carotenoid in maize. Molecules 17: 1125511268.

Rodriguez-Amaya, D.B. \& Kimura, M. 2004. Handbook for Carotenoid Analysis. HarvestPlus Technical Monograph 2. Washington, DC and Cali. p.3.

Roohinejad, S., Oey, I., Everett, D.W. \& Niven, B.E. 2014. Evaluating the effectiveness of $\beta$-carotene extraction from pulsed electric field-treated carrot pomace using oil-in-water microemulsion. Food Bioprocess Technol. 1: 3336-3348.

Shahidan, N. 2014. Production of carotenoid in pumpkin (Cucurbita moschata) through biogenesis manipulation. $\mathrm{PhD}$ thesis. International Islamic University. Malaysia.

Shi, J., Mazza, G. \& Maguer, M.L. 2002. Functional Foods: Biochemical and Processing Aspects. New York: CRC Press.

Ministry of Agriculture (MOA). 2013. Statistik Tanaman. Sub sektor tanaman makanan. Unit perangkaan-bahagian perancangan, teknologi maklumat dan komunikasi, Jabatan Pertanian Semenanjung Malaysia. http://www.moa.gov.my/ web/guest/buku-perangkaan-agro-makanan.

Strati,I.F. \& Oreopoulou, V. 2011. Effect of extraction parameters on the carotenoid recovery from tomato waste. International Journal of Food Science and Technology 46: 23-29.

Tan, P.W., Tan, C.P. \& Ho, C.W. 2011. Antioxidant properties: Effects of solid-to-solvent ratio on antioxidant compounds and capacities of pegaga (Centella asiatica). International Food Research Journal 18: 557-562.

Wang, L. \& Liu, Y. 2009. Optimization of solvent extraction conditions for total carotenoids in rapeseed using response surface methodology. Natural Science 1: 23-29.

Warkoyo \& Saati, E.A. 2011. The solvent effectiveness on extraction process of seaweed pigment. Makara, Teknologi 15: 5-8.

Xanthopoulou, M.N., Nomikos, T., Fragopoulou, E. \& Antonopoulou, S. 2009. Antioxidant and lipoxygenase inhibitory activities of pumpkin seed extracts. Journal of Food Research International 42: 641-646.

Norshazila, S., * Koy, C.N., Ho, L.H.,Azrina, I., Nurul Zaizuliana, R.A. \& Zarinah, Z.

Faculty of Bioresources and Food Industry

Universiti Sultan Zainal Abidin, Tembila Campus

22200 Besut, Terengganu Darul Iman

Malaysia

Rashidi, O.

International Institute for Halal Research and Training

International Islamic University Malaysia

50728 Kuala Lumpur, Federal Territory

Malaysia

*Corresponding author; email: norshazila@unisza.edu.my

Received: 1 November 2015

Accepted: 10 May 2016 